23. Russo, Zh.-Zh. (2001). Pro suspil'nu ugodu, abo Pryncypy politychnogo prava [On social agreement, or Principles of political law]; ukr. per. $\mathrm{z}$ fr. ta kom. O. Homa. Kyiv: Port-Royal [in Ukrainian].

24. Lokk, Dzh. (1988). Sochinenija [Works]. (Vol. 3). Moscow: Mysl' [in Russian].

25. Zombart, V. (2004). Burzhua. Evrei i hozjajstvennaja zhizn' [Bourgeois. Jews and economic life]. Moscow: Ajris-press [in Russian].

26. Hajek, F. A. (2006). Pravo, zakonodatel'stvo i svoboda: Sovremennoe ponimanie liberal'nyh principov spravedlivosti i politiki [Law, legislation and freedom: A modern understanding of the liberal principles of justice and politics]. Moscow: IRISJeN [in Russian].

27. Pipes, Richard. (1990). The Russian Revolution 1899-1919. Collins Harvill, London, 944 p. [in English].

28. Kravchenko, A., \& Kyzymenko, I. (2019). The Forth Industrial Revolution: New Paradigm of Society Development or Posthumanist Manifesto. Philosophy and Cosmology. (Vol. 22), (pp. 121-128) [in English].

BOICHENKO Mykhailo,

DSc (Philosophy), Professor,

Professor at the Department of Theoretical and Practical Philosophy,

Taras Shevchenko National University of Kyiv.

Volodymyrska Street, 60, Kyiv, 01033, Ukraine

E-mail: boychenko m@univ.net.ua

ORCID: https://orcid.org/0000-0003-1404-180X
BOICHENKO Nataliia,

DSc (Philosophy), Professor,

Professor at the Department of Philosophy, Shupyk National Medical Academy of Postgraduate Education.

Dorohozhytska Str., 9, Kyiv, 04112, Ukraine

E-mail:nboychenko@ukr.net ORCID: https://orcid.org/0000-0001-8793-7776

SHEVCHENKO Zoia,

$\mathrm{PhD}$ (Philosophy), Docent, Associate Professor at the Department of Philosophy and Religious Studies, Bohdan Khmelnytsky National University of Cherkasy. 81 Shevchenko Boulevard, Cherkasy, 18031, Ukraine

\title{
THE ETHICAL AND ECONOMIC CONDITIONS OF HUMAN BIRTH AS A PHILOSOPHICAL PROBLEM
}

The basic economic and ethical arguments in favor of proper treatment of human birth are considered. It has been analyzed that ethics should be widely considered when defining goals and means of economic behavior. It has been argued that utilitarianism as an ethical position should be limited in practice, but bioethics should be more widely used in determining the motivation for economic behavior.

Keywords: human birth, ethics, economics, causes and effects, values, rational choice.

(C) Boichenko M., Boichenko N., Shevchenko Z., 2020 
Бойченко М., Бойченко Н., Шевченко З. Этические и экономические условия рождения человека как философская проблема. Рассмотрены основные экономические и этические аргументы в пользу надлежащего отношения к рождению человека. Проанализировано, что этику следует больше учитывать при определении иелей и средств экономического поведения. Доказано, что утилитаризм как этическая позищия должен быть ограниченным на практике, зато биоэтику следует шире применять при определении мотивации экономического поведения.

Ключевые слова: рождение человека, этика, экономика, причины и следствия, ценности, рациональный выбор.

Background. The birth of a person is the result of a whole set of causes, on the one hand, and has a number of goals and consequences on the other. In this whole world of determinations and relationships, representatives of different sciences view only segmentally, with each segment more complementing the other, but only partially intersecting with it - so that the complex of determinations and relationships studied by every special science does not completely explain, or minimally explains the complex of determinations and relationships that other, even related, science studies. Only the holistic study of the world of human birth can reveal the completeness of the conditions of this birth. And the philosophy is trying to unravel this entire world - to explain in their entirety all the conditions, rational as well as irrational, that each time uniquely enable the birth of particular person. Economic reasons are often used to take like most rational and realistic whereas ethical reasoning seems to be something unreal and irrational. Still in real life the very ethical imperatives were all-in-all the main motivators to economic behavior. The choice to facilitate the birth of a child is one of such vivid example.

Analysis of recent research and publications. Social philosophy and ethics reveal several social determinations and relationships around human birth. Of particular interest it is the correlation of economic and ethical determinations. We could distinguish three areas of the scientific discussion about ethical and economic conditions of human birth: framework conditions for social development as conditions of human birth; economic and ethical understanding of the value of human life; social and biological identification of a person at birth.

Framework conditions for social development as conditions of human birth are investigated first of all by sociologist, political philosophers and ecologists. British thinker Arthur Caplan [1] is looking for moral values as a reason for people to give birth and growing up the children in appropriate way. Contemporary German ecologists, scientists and politicians Ernst Ulrich von Weizsäcker and Anders Wijkman [2] made an accent on the problem of overpopulation of the Earth.

Economic and ethical understanding of the value of human life is enough elaborated, but from opposite values: according to German philosopher Jens Timmermann recent investigations of Immanuel Kant theory he took the rigorist ethic position [3], Turkish philosopher Mesut Sert study of Werner 
Sombart theory [4] - Sombart took almost the biological position, while according to recent investigation of Danish Professor of Business Ethics at Roskilde University Jacob Dahl Rendtorff German philosopher Peter Koslowski took almost theological position [5]. German sociologists and philosophers Max Weber, Max Scheler, American philosopher John Dewey and contemporary French philosopher Jean Baudrillard tried to find a proper composition and balance between economic and ethical position and American ethicists David B. Resnik and Kevin C. Elliott came to the similar position now [6].

Social and biological identification of a person at birth was a topic for ethics, biologists and researchers in the field of cultural studies, but for some philosophers as well. American philologist, a founder of the academic field of postcolonial studies Edward Said according to Fikret Guven made a disclosure of cultural basis of social identity [7]. British ethologist Richard Dawkins [8] and American biologist Siddharhta Mukherjee [9] take confront positions in issue of abortion. Ethical approach to solving such confrontation could be formulating with help of some contemporary Norwegian ethicist Torbjörn Tännsjö’s [10] ideas.

In each of these areas there are several prominent publications classic as well as recent - but a general philosophical view on these conditions is lacking.

The aim of the article will be to find out integrity of all determinations and relationships around human birth by examining the mutuality of ethical and economic conditions of it.

Materials and methods. The issue is based on analysis of philosophical texts on the problem of economic and ethical motivation of human behavior. The methodology of the article takes into account the importance of human life as a social value. A basic methodology in this study is an axiologically rethought of Pierre Bourdieu's structural constructivism [11]. It should reveal the correlation of existing value structures with the creation of new values by people: first of all about the correlation of moral values and ethical ideals.

Results. Framework conditions for social development as conditions of human birth.

All attempts to comprehend the conditions of birth of a person with a high probability can lead to two opposite results: either a cynical formal and rational variant calculation of the benefits of birth, or a value-rational opportunistic assertion of absolute inviolability of life. The first option is classically considered utilitarian theory of morality, the second - the Catholic concept of the sanctity of life as such. Each has its own strong arguments, but each has serious drawbacks that will be discussed. In any case, neither one nor the other can be methodology of our study - after all, these are theories that not only exclude one another but also do not take proper consideration of the subject area of one another. 
By the way, not only utilitarianism or Catholicism considers the problem of fertility from a philosophical point of view. At the same time it is necessary to carry out only preliminary prepared ethical researches, without trying directly to apply ethical theory to life situations. The initial dilemma we take for consideration is the dilemma of ethical and economic attitudes toward human birth.

The birth of a child is never an accident - not only in human society, but also in other social communities that form almost all living organisms. However, the reasons for choosing a child's future father by child's future mother, as well as the mother by the father are significantly different from the reasons in the world of animals. French philosopher and sociologist Pierre Bourdieu identified features of a "matrimonial strategy" of people, which, although not amenable to exhaustive rationalization, still are not the result of blind action by biological forces. In particular: "Matrimonial strategies are often the resultant force relations within a family group, and these relationships can only be understood by referring to the history of that group, in particular, the history of previous marriages" [11, p. 106]. However, there are a number of other, more general conditions, both social and natural, in particular biological, in addition to the family, intimate conditions of human birth. All of them are somehow reflected on family terms, expressed in them. However, in order to see and understand these complex determinations in seemingly obvious and simple family relationships, one must first clearly state these externalities to the family, the social and natural conditions that determine it.

The human right to birth is at first sight one of the most obvious natural human rights [12]. However, such an attitude may seem anthropocentric, humanism can be regarded as an attempt of a person to wish what he or she wants to be true for everyone and everything in the world. On the other hand, the natural sciences are inclined towards an impartial and, to some, non-anthropological view on human birth. Yes, the representatives of the Club of Rome pay attention to the problem of overpopulation of the planet Earth [2], and in this light, the problem of human birth becomes already a problem for all living things - humans more displace all other species of life on the planet, rather than facilitate their conservation and free further evolution. Thus, high birth rates have become an environmental problem for all other species on the planet. But for humanity itself, the high birth rate, as well as the birth of a person, is not in itself an obvious blessing, as it seems to most modern humanities. At one time, Thomas Malthus [13], and earlier Jonathan Swift, drew attention to the economic disadvantage of high fertility: by itself, without taking into account the development of science, increasing production efficiency and other factors of human development, high fertility leads to increased poverty, famine and premature death. Swift even sarcastically suggested a "simple and effective solution" to this problem if given permission to use poor children as a food resource [14, p. 6]. 
Despite all the savagery of such a proposal, from a moral point of view, it does not look so irrational from a naturalistic, "economic" point of view. However, as Swift had expected, British society at one time was horrified by this prospect - and it still looks horrible today.

All this draws attention, in particular, to the relation between ethics and economics as the point of intersection of humanitarian and natural, social and biological views in general and in the issue of human birth in particular. An important role in this could and should play a bioethics defining the boundaries of human life, for example helps to define the moral and legal status of the human embryo. Even without delving into the medical and legal side of the case, one can acknowledge the inevitability of an ethical view of the human right to birth, with which economic science must be considered. But for this ethical judgment must also take economic rationality into account, not deny of it.

Arthur Caplan rightly points out: "These days, it is uncommon to hear commentators on higher education accuse those who spend time studying the humanities in college or university of being foolish. The idea that a person might take courses in philosophy, psychology, religion, the arts, sociology or politics strikes many as simply ludicrous ... how utterly wrong are those people who see the value of education only in terms of a career opportunities it creates ... the discoveries, inventions, and findings that make the most difference in our lives are just as likely to emanate from the humanities and social sciences side of the intellectual landscape as they are from technology, science, and engineering" [1, p. 6]. This impact, however, is not at all obvious if it has to be constantly reminded and explained. This influence itself does not require any special recognition of the public - the important fact is the constant perception by the "physicists" the ideas of "lyricists", as well as perception by economists the ethical arguments. This fact explains, above all, not the magical charm of "lyricists" and not the indestructible naivety of "physicists", but the simple and inviolable truth: although the science describes the world of nature, science still serves human beings and humanities study and knows human needs better then science. However, there are several related circumstances that require special and additional clarification and argumentation in favor of the humanities. The main among them is the need to formulate adequate motivation for the choice of humanitarian specialties by talented entrants for further education.

The formation of due respect for humanities among economists is primarily important - both for students and their professors, economists in the field of economy as well as others in non-academic applied fields. It seems that educators and economists, each individually, are not viewed these tasks as interconnected - while their successful solution seems to be deeply interdependent. In particular, bioethics exemplifies that ethics-based education trains not only economists and entrepreneurs who are able to 
produce goods and services without failing ethical standards, but also consumers ready to support ethically responsible production through their choices of purchases. Mutual concern of producers and consumers - not only in the sphere of economy, but also in the sphere of ecology, in the sphere of politics, in other vital spheres of society, to create the preconditions for transformation of all social life on new bioethical grounds.

It is important that the movement from ethics to economics and from economics to ethics is not merely counter-intuitive but coherent in order to avoid a scenario that, while seemingly facing each other, ethics and economics would not disperse, "like ships in the sea" that is, with parallel courses. After all, there is a real danger - and not just a theoretical one that ethical economics and economic ethics can be formed in parallel, and not help but interfere with each other, forming not only different but sometimes incompatible practical recommendations. The prospect of overcoming such a fatal coincidence is offered by bioethics. This may not be the only means of reconciling the interests and values of ethics and economics, but today it is considered as one of the least developed and still one of the most promising. However, it is first necessary to define more clearly the mutual dispositions of ethics and economics.

Economic versus ethical understanding of the value of human life.

The tendency for the separation of ethics and economy has emerged a long time ago, later it only deepens. Even in the modern Christian economic ethics by Arthur Rich [15], we come across ideas of an economy focused on the common good rather than the pursuit of private entrepreneurial interest.

At the same time, Werner Sombart points to a key difference between Christian ethics and economic logic: Christian love and concern for a peaceful life goes against the competition practices on which the modern market economy is based [4; 16, p. 122]. "All the qualities of an entrepreneur we have come to know as the necessary conditions for success: resoluteness, stability, perseverance, tirelessness, rapid focus on a goal, toughness, courage to take risks, daring - all of these are rooted in the powerful, life-giving worth above the average level of vitality. Rather, the obstacle to the activity of the entrepreneur is, on the contrary, the strong development of inclinations to the feeling, which usually creates a strong superiority of sensual values"* $[16$, p. 153]. Sombart also names several other prerequisites for the development of capitalism, but the most effective one is the entrepreneurial activity that is driven by a "powerful life force". Thus, Christian-theologically-minded thinkers put the conditions before the economy, regardless of market considerations, while market defenders such as Sombart insist on the autonomy of economic activity and on its internal ethos of economic victories and the rule of the winner of market competition. Sombart particularly urgently insists on the honesty of the victories of a true entrepreneur

* All quotations from foreign language sources are given in the translation of the authors of the article.

ISSN 1727-9313. BICHИK KHTEY. 2020. No 
who develops production, and contrasts this "honest" economic affair with financial speculations as an activity of "Händler", who only parasites the classical economy and destroys it [16, p. 206-213].

However, already modern representative of economic ethics Peter Koslowski goes back to rigorism of ethical autonomy, from which he, in the spirit of Kant's own philosophy, tries to derive the rules of economic behavior from moral law (though already bypassing religion) - just as Kant, deduced the right, and perhaps even partially, the policy from the ethics [3]. According to Kozlowski, economic ethics "is an ethical theory that uses economic tools of analysis, ethical theory related to economics, just as political economy is a political theory that uses economic analytical tools" [17, p. 8]. Jacob Dahl Rendtorff wrote: "...there is a close interaction between culture, ethics and economics in the definition of the basis for economic markets. According to the definition of Koslowski, economic ethics or ethical economy is a theory of the economy and of ethics. As an ethical economy, it unites ethical and economic judgments and constitutes the complement of political economy" [5]. But this argumentation itself does not give non-religious ethical grounds for economic activity.

That is why many have considered utilitarianism as the most "materialistic" version of ethics: if ethics is what is good for the individual, including what is beneficial to them, than this would seem to be a true ethic of economic activity! However, in real life, everything is not so straightforward and not so simple. Even utilitarianism does not treat all personal goods as benefits - John Stuart Mill distinguishes between high and low pleasures [18], thus eliminating the possibility of reducing all benefits to material. Value ethics and virtue ethics not only decisively derive ethical justification beyond material goods but also offer a radically different understanding of economics itself - namely, in Aristotle's spirit as a common good (in which security and material wealth are not the only public good), or in the style of the philosophy of values of Max Scheler [19] and John Dewey [20], who undoubtedly place spiritual and intellectual values above material ones as priority motivators of human behavior - both political and economic. The difference with Kant and Koslowski's deontology is that ethics here does not impose a "cynical" economy on the outside of its norms, and the economy itself is regarded as intrinsically humanistic.

On the one hand, a simple and reckless orientation only to the profit of the utilitarian version of the "economic man", of course, ultimately leads to the deepening of the global crisis of humanity: in a war as well as in a situation of aggravation of the crisis, someone dies, but some, few, but the cynical and fast one who adopting new rules of the game, gets much faster and much more enriched. Therefore, as the media are somehow interested in developing terrorism as the best provider of the most "interesting" news (which Jean Baudrillard has convincingly argued in the recent past [21]), the crisis for the most typical "economic men" is a wonderful window of oppor- 
tunity, not a disaster. If for most people the crisis is lossmaking, and for some of them even carry premature and painful death, such a general situation cannot serve as a basis for economic development. The short-term and easy enrichment of some does not create incentives for the development of the economy as a whole and the sharp decline in purchasing power of most people will inevitably result in the loss for all market participants.

On the other hand, in order to be practically successful, any ethical position, even seemingly the most correct theoretically and autonomously in its moral rightness, must find the logic of profitable economic activity associated with it [6]. In fact, the strongest ethical position is that which provides the most profitable economic action strategy. A classic example is Max Weber's research on the selective affinity of Protestant ethics and the spirit of capitalism. At one time, as Weber showed, the most rigorous ethical justification for certain ways of pursuing benefits was one of the main sources of the initial modernization of all European civilization [22]. It could be assumed that this was an exceptional social phenomenon, but if one carefully studies the history of mankind, it turns out that all of it is based on exceptional events. The number of such events does not decrease over time, but only grows: humanity is constantly engaged in creativity, changing not only its environment, but also itself - thanks to all new discoveries, new ideas [1]. Ethics is not the only generator of new ideas in all spheres of knowledge, but in the field of social relations - it is probably the very case. The bioethics is in the same situation as economic theory and practice that is forced to re-examine its grounds in the light of recent circumstances, when both the sources and applications of social wealth change dramatically, and the understanding of essence of public wealth that should be reconsidered.

Social and biological identification of a person at birth.

The human social and biological identity are interrelated, and if in traditional society biological identity has predominantly defined social identity, then in modern society, social identity increasingly defines biological identity. If, from birth, the child, along with his or her race, ethnicity, gender, health status, has already acquired a certain "corridor" of social opportunities, now these characteristics either lose their decisive influence or may be altered. Most recently a non-Caucasian, female, or child with a disability had very little opportunity to build a successful social career. Although previously such a violation of social and human rights was considered something natural and self-evident, it is now clearly visible the ideological, economic and cultural grounds for such decisions. Postcolonial studies, such as Edward Said's works, may serve as a distinct but striking example of disclosure of such prejudices [7;23]. However, some biological characteristics are still the subject of discussions, for example in considering of abortion or negative pregnancy recommendations. But now it is becoming increasingly apparent not biological, but rather the social justification for decisions in favor of a positive or negative solution to such issues. 
Let us consider not the anachronisms, but the first cases of new problems of social assessment of human biological identity. Among them, medical practice cases are particularly illustrative and already well-analyzed. To the analytics already done, sometimes it is enough to just add some philosophical appraisals to get them into an advanced form that gives grounds for a confident ethical stance. But such situational ethical analysis is not a sufficient - one should take a proper ethical theory for it. Indeed, critic of the theological approach and the popularizer of science, Richard Dawkins proposes, on the basis of medical research, and in particular genetic analysis, to make abortion decisions or to ban children from couples who have a high probability of birth children not only with genetic diseases, but also with a genetic predisposition to "ordinary" diseases. In particular, Dawkins points out that "But it's safe to say an early embryo before the nervous system develops can no more feel pain than a pumpkin or a beetroot" [8], and from this concludes the moral safety of abortion at an early stage of pregnancy. Moral arguments in favor of abortion are manifested in Dawkins as a means, while the goal is closer to economic considerations: a sick child will not be a source of income for economy, but rather a bottomless pit, a cost item that will always be unprofitable. At the same time most of utilitarians accept that a sick child will suffer, and therefore he or she will not want to live $\mathrm{him} /$ herself. In the contrast, one can refer to the position of the Siddhartha Mukherjee, who, on the example of his own family history, shows how carriers of one gene care about each other, including sick family members [9]. Such care makes them all happy. Such care is the motivation for everyone of them to work better enough to provide the whole family. The selfish of misinterpreted utilitarianism and the misinterpreted gene theory by Richard Dawkins contrasted to collectivism and moral virtues in justifying a social behavior strategy based on the knowledge of genetics by Siddhartha Mukherjee. In our view, the second position is a much better and more stable justification for economic behavior than the first.

Dawkins' like-minded people are even ready to edit the human genome to exclude such bodily characteristics in genome carrier, such as the propensity to gain weight. However, more thorough genome studies show that not individual genes but gene combinations are usually responsible for certain human biological characteristics. Thus, the genome plot "responsible" for obesity is likely to, in combination with other sites; provide other, important and useful human characteristics [24]. Therefore, by "excluding" obesity, the genome editor can "exclude" a number of important for human qualities, and the entire positive, as well as all the negative consequences cannot be calculated. If only some of the properties of the genome regions are known to mankind, even a careful study of them will never give an answer as to their full significance to humans, and all the characteristics of the genome will never be known. This requires the development of a certain respectful 
attitude towards the biological basis of human identity and the introduction of certain restrictions and warnings regarding social interventions. But such respectful attitude itself is the social position.

Criticizing theology and, in general, creationism as the epistemological position on which theology is based, one should not, however, reject the moral arguments to which they refer. After all, the sanctity of life is a concept that we believe is more widely used than just the sphere of religion. The value of the sanctity of life may be based on the values of God or the absolute, but it may itself be the basic value on which other values are based. Albert Schweitzer considers the sanctity of life as unconditional and without further justification [25], also apparently close Van Rensselaer Potter [26] and Peter Singer [27] recognized it. In fact, this position includes all those who do not dare to give one last word in deciding not to have a baby - and yet dare to give birth.

Cases of paternity, surrogacy, etc. are just the application of this general principle of the sanctity of life. One can read more about questions similar to the test-tube baby case: the case of the baby from three parents [28], the Baby K. case [29] and more. But in any case, it may be a desire to promote the birth of a child as a primary goal. Only under this condition it is possible to take into consideration the question, what to do with the so-called "genetic material", which was not used for the birth of the baby. Only then, there are no questions about any third-party experiments with this material, only then there is no question of improper handling of embryos, etc.

Conclusion. Modern economic theory and practice are increasingly based on ethical theory and practice. For example, bioethics becomes not only means for justification, but also to motivation of economic behavior. If we remain at the positions of utilitarian ethics, then, at first glance, human embryo looks like "genetic material" and cannot be identified not only as a potential person, and accordingly the various utilitarian uses that may result in economic benefits contrary to the values of humanism. So utilitarianism as ethical position seems to be practically limited applicable. Thus, the issue of birth decisions is increasingly dependent from the social identity understandding: for example, recognizing the social properties of an embryo is a decisive argument against abortion, while some researchers consider it doubtful enough to terminate pregnancy.

The due economists' respect for humanities is primarily important for the successful development of economics and economy. Although the science describes the world of nature, science still serves human beings, and humanities discover human needs better then science. In order to be practically successful any ethical position should find the logic of profitable economic activity associated with it. Ethics is one of the main generators of new ideas in the field of social relations. Ethics of values and ethics of virtues not only decisively derive ethical justification beyond material goods but also offer a radically different understanding of economics itself. 


\section{REFERENCES}

1. Caplan, A. (2015). Preface. In: Arp, R. (Ed.) 1001 ideas that changed the way we think: Human Knowledge on Philosophy, Politics, Science, Art, Religion, Society and More. London: Imprint Cassel Illustrated [in English].

2. Weizsäcker, Ernst Ulrich von; Wijkman, Anders (2018). Come On! Capitalism, Short-termism, Population and the Destruction of the Planet. A Report to the Club of Rome. Springer Science+Business Media LLC [in English].

3. Timmermann, Jens (Ed.) (2009). Kant's 'Groundwork of the Metaphysics of Morals'. A Critical Guide. New York: Cambridge University Press [in English].

4. Sert, Mesut (2018). Werner Sombart and His Analysis of "The Future of Capitalism". Economic and Management Issues in Retrospect and Prospect IJOPEC Publication, 9-22 [in English].

5. Rendtorff, Jacob Dahl (2016). Peter Koslowski's Ethics and Economics or Ethical Economy. A Framework for a research agenda in business ethics. NordicumMediterraneum, 10(3). Retrieved from https://nome.unak.is/wordpress/volume10-no-3-2016/conference-paper-10-3/peter-koslowskis-ethics-and-economics-orethical-economy-a-framework-for-a-research-agenda-in-business-ethics [in English].

6. Resnik, David B., \& Elliott, Kevin C. (2016). The Ethical Challenges of Socially Responsible Science Account Res. 23(1): 31-46. DOI: 10.1080/08989621.2014.1002608 [in English].

7. Güven, Fikret (2019). Criticism to Edward W. Said's Orientalism. RumeliDE Dil ve Edebiyat Araştırmaları Dergisi, (15), 418-430. DOI: 10.29000/rumelide.580700 [in English].

8. Dawkins, Richard (2017). An Exchange On Abortion. Retrieved from https://www.richarddawkins.net/2017/11/an-exchange-on-abortion [in English].

9. Mukherjee, Siddhartha (2017). The Gene: An Intimate History New York: Large Print Press [in English].

10. Tännsjö, Torbjörn (2019). Setting health-care priorities What Ethical Theories Tell Us. New York: Oxford University Press [in English].

11. Bourdieu, Pierre (1987). Choses dites. Paris, Minuit [in English].

12. Malthus, Thomas Robert (1999). An Essay on the Principle of Population. Oxford: Oxford University Press [in English].

13. Boichenko N. M. (2019). Cinnist lyudskogo zhittya: etiko-pravovi aspekti. Pravove regulyuvannya temporalnih mezh zhittya lyudini: materiali zasidannya "kruglogo stolu", Kyiv, 22 zhovtnya 2019 r. ukladach Ya.O. Trinova. Kyiv [in Ukrainian].

14. Swift, Jonathan (2008). A Modest Proposal. BOOK JUNGLE [in English].

15. Rich, Arthur (1984). Wirtschaftsethik. Grundlagen in theologischer Perspektive. Gütersloh: Gerd Mohn [in English].

16. Zombart, V. (1994). Burzhua: E'tyudy' po istorii dukhovnogo razvitiya sovremennogo e'konomicheskogo cheloveka. Trans. In-t socziologii. Moscow: Nauka [in Russian].

17. Koslowski, Peter (2001). Principles of ethical economy. Dordrecht: Springer [in English].

18. Mill, J. S. (2001). Utilitarianism. Kitchener: Batoche Books [in English].

19. Scheler, Max (1973). Selected Philosophical Essays. Northwestern University Press [in English].

20. Dewey, John (1919/2009). Democracy and Education: An Introduction to the Philosophy of Education. Create Space Independent Publishing Platform [in English]. 
21. Baudrillard, Jean (1999). Fatal Strategies (Phil Beitchman and W. G. J. Niesluchowski, Trans). Jim Fleming (Ed.). New York: Autonomedia [in English].

22. Weber, Max (2010). Die protestantische Ethik und der Geist des Kapitalismus, Vollständige Ausgabe. Herausgegeben und eingeleitet von Dirk Kaesler, 3, durchgesehene Auflage. München: Beck [in English].

23. Said, Edward W. (1978). Orientalism. New York: Pantheon [in English].

24. Weight Management (2004). State of the Science and Opportunities for Military Programs Washington (DC): National Academies Press [in English].

25. Schweitzer, Albert (1948). Kultur und Ethik. Kulturphilosophie, zw.Teil. Olavs Petri Vorlesungen an der Universität Upsala. München: Biederstein, 7. Aufl. XXVI, 269 [in English].

26. Potter, Van Rensselaer (1971). Bioethics: Bridge to the future. Englewood Cliffs, N. J. Prentice-Hall [in English].

27. Singer, Peter (2001). Animal Liberation. Ecco Press [in English].

28. Dytyna vid tr'oh bat'kiv: pershyj v sviti maljuk za unikal'nym metodom narodyvsja v Ukrai'ni (2017). 24tv.ua. Retrieved from https://24tv.ua/health/ ditina_vid_troh_batkiv_pershiy_v_sviti_malyuk_za_unikalnim_metodom_naro divsya v ukrayini n771947 [in Ukrainian].

29. Doyle D. (2010). Baby K. A Landmark Case In Futile Medical Care. WebmedCentral MEDICAL ETHICS 1(10): WMC00969. Retrieved from http://www.webmedcentral.com/article_view/969 [in English].

The article submitted to editor's office on 28.01.2020.

\begin{abstract}
Бойченко М., Бойченко Н., Шевченко 3. Етичні та економічні умови народження людини як філософська проблема.

Постановка проблеми. Народження людини, щзо є результатом дії цілого комплексу причин, має перед собою низку иілей та наслідків. Увесь иеей иілісний світ детермінацій та зв'язків намагається розкрити філософія - пояснити усі рачіональні та ірраціональні умови, які щчоразу унікальним чином уможливлюють народження саме иієї конкретної людини. В реальному житті саме етичні імперативи були основними мотиваторами економічної поведінки. Вибір сприяння народженню дитини - один з таких яскравих прикладів.
\end{abstract}

Аналіз останніх досліджень $і$ публікацій показав, щңо попри наявність окремих наукових доробок, залишається невирішеною важлива науково-практична проблема щзодо визначення співвідношення етичних та економічних чинників людської поведінки загалом і прийняття рішення щзодо народження дитини зокрема.

Мета статті - з'ясувати циілісність усіх детермінацій та взаємозв'язків навколо народження людини, вивчаючи взаємозалежність етичних та економічних його умов.

Матеріали та методи. У процесі дослідження використано метод аксіологічно переосмисленого структурного конструктивізму П'єра Бурдьє.

Результати дослідження. Висунуто гіпотезу про існування залежності між економічно успішною поведінкою $і$ ї̈ належним етичним обтрунтуванням, наприклад, щзодо прийняття рішення про народження людини. За результатами иього дослідження запропоновано, зокрема: відійти від практики протиставлення економічної етики як теорії рачіональної поведінки і етичної економіки як такої, щзо ригористично приписує економіці моральні приписи; розробити більш розгорнуту етичну мотивацію економічної поведінки на основі аналізу наявних моральних практик; обмежити застосування етики утилітаризму в економічній теорії і практиці; звернутися до базових принциипів біоетики при виріменні питань народження дитини; визнати пріоритетність соціальної ідентифікації особистості над біологічною тощзо. Реалізація ичих пропозицій сприятиме співвіднесенню вирімення питання народження людини зі стратегією економічного розвитку суспільства.

ISSN 1727-9313. ВІСНИК КНТЕУ. 2020. № 
Висновки. Економічна теорія та практика дедалі більше трунтуються на етичній теорії та практиці. Наприклад, біоетика стає не тільки засобом для виправдання, а й для мотивації економічної поведінки. Якщо ми залишимося на позиціях утилітарної етики, то, на перший погляд, людський ембріон виглядає як "генетичний матеріал", і його можна не лише не ідентифікувати як потенційну людину, але, відповідно, можна знайти йому різноманітне утилітарне використання, яке може мати своӥм наслідком економічні вигоди, шзо суперечать иінностям гуманізму. Тому утилітаризм як етична позиція є практично обмежено застосовним. Таким чином, питання рішень про народження дедалі більше залежить від розуміння сочіальної ідентичності: наприклад, визнання соиіальних властивостей ембріона є вирімальним аргументом проти абортів, тоді як деякі дослідники вважають цее досить сумнівним для припинення вагітності.

Належна повага економістів до гуманітарних наук передусім важлива для успішного розвитку економічної теорї та практики. Природничі науки, описуючи світ природи, все ще служать людині, проте гуманітарні науки виявляють потреби людини кращзе, ніж природничі. Для того, щзоб бути практично успішною, будь-яка етична позиція повинна знайти логіку вигідної економічної діяльності, пов'язаної з нею. Етика є одним з головних генераторів нових ідей у сфері сочіальних відносин. Етика цінностей $і$ етика чеснот не лише визначально виводять етичні обтрунтування поза матеріальними благами, але й пропонують кардинально інше розуміння самої економіки.

Ключові слова: народження людини, етика, економіка, причини і наслідки, цінності, раціональний вибір.

БОНДАРЕВИЧ Ірина,

к. філос. н., доцент, доцент кафедри філософії

Національного університету "Запорізька політехніка"

вул. Жуковського, 64, м. Запоріжжя, 69061, Україна

E-mail: bondarevych@ukr.net

ORCID: https://orcid.org/0000-0002-6711-8244

\section{СПЕЦИФІКА СОЦІАЛЬНИХ ПРАКТИК ДОВІРЧИХ ВІДНОСИН У ПЕРЕХІДНИХ СУСПІЛЬСТВАХ}

Стаття присвячена пошуку прогностичних підходів до визначення динаміки трансформації перехідних суспільств, дослідженню соиіальних практик довірчих відносин - стосунків любові. 3'ясовано, щзо вимірювання інтенсивності, варіативності, сфер розповсюдження, кількості адептів соціальних практик стосунків любові, а також моделювання процесів їх розгортання на рівні мотивацій індивідів, узвичаєних сочіальних дій та існуючих сочіальних інституцій є ефективним у прогнозуванні перебігу суспільних трансформацій у нестабільних умовах.

Ключові слова: перехідне суспільство, соціальне прогнозування, соціальні практики, габітус, довірчі відносини, симулякри любові, опановані цінності любові.

(C) Бондаревич I., 2020 